Available online at GSC Online Press Directory

GSC Biological and Pharmaceutical Sciences

e-ISSN: 2581-3250, CODEN (USA): GBPSC2

Journal homepage: https://www.gsconlinepress.com/journals/gscbps

(RESEARCH ARTICLE)

\title{
Carried hepatitis B among Libyan patients who attended the Al Zawia street hospital
}

\author{
Khaled Ali Alawaini 1, ${ }^{*}$, Numidya Ali Omar ${ }^{2}$, Hunida Saed Alhush ${ }^{2}$, Eman Yakhlef kamkoum ${ }^{2}$ and Esra \\ Ahmed Alazabi 2
}

${ }_{1}$ Student at a memorial university, Biochemistry department. Canada.

${ }^{2}$ Higher institute of science and medical technology/Jado, Libya.

Publication history: Received on 26 September 2020; revised on 05 October 2020; accepted on 10 October 2020

Article DOI: https://doi.org/10.30574/gscbps.2020.13.1.0312

\begin{abstract}
Hepatitis B (HBV) is a significant liver disease that affects roughly 400 million individuals globally with chronic infection, leading to liver cirrhosis or carcinoma. The virus can spread through blood transfusion, sexual contact, or the use of contaminated needles. HBV is more prevalent in developing countries than developed ones. However, it is estimated that $5 \%$ to $10 \%$ of the global population carry the virus, whereas, in North America and western Europe, only $1 \%$ of the people have a chronic infection. Our objective is to determine the prevalence of HBV and identify the disease's risk factors. We conducted a statistical study, and data were collected through the Al Zzawia street hospital from November 1, 2010, to January 1, 2011. Our results concluded that the prevalence of HbsAg was higher in 2005 than in 2010. HBV was also found to be more prevalent in males than in females. As a result, more attention and guidance, especially for young people, could reduce the spread drastically.
\end{abstract}

Keywords: HBV; Liver; Virus; Infection

\section{Introduction}

Hepatitis B virus (HBV) is a common viral disease that is a considerable health problem worldwide (1). The World Health Organization (WHO) estimated that about 2 billion people are exposed to the virus, 3.3\% from the Eastern Mediterranean Region (2) chronically infected with HBV, and 350 million subjects. HBV leads to acute and chronic liver disease worldwide (3), including liver cirrhosis (LC) and hepatocellular carcinoma (HCC), accounting for 0.5 million to 1.2 million deaths per year (4). HBV can spread through risk blood transfusion, sexual intercourse, intravenous drug abuse (5), contact with infected bodily fluids, and the use of improper injection techniques (6). HBV remains viable on surfaces for at least a week. Persons with chronic infection (presence of HbsAg in the serum more than six months following acute infection) (7). More than one million infected people are killed by complications due to the virus annually worldwide, which is $2.7 \%$ of total deaths (8). People who were infected early in life are at high risk of developing cirrhosis or liver carcinoma 15\% to 30\%, leading to premature death (9). HBV or the "Australia antigen" was discovered in 1965 by Baruch Blumberg (10) and later identified as the hepatitis B virus surface antigen (10). HBV is a small double-stranded DNA genome (11), approximately $3.2 \mathrm{~kb}$ in size (12); it belongs to the Hepadnaviridae family $(7,12)$. The severe type of hepatitis is known as hepatitis B or HBV. The surface antigen of the virus (HBsAg) is one of the earliest serums present in HBV infection, and because it persists, HBsAg is vital to the diagnosis of HBV infection. Other serum markers of HBV infection include the HBV envelope antigen (HBeAg) and the HBV core antigen (HBcAg) (13). Some individuals can develop acute HBV infections and then achieve complete immune clearance, yielding lifelong immunity. In contrast, others can develop chronic HBV infections depending on the host's immune response (14). Many studies estimated that about $10 \%$ of patients with acute hepatitis B virus (HBV) would progress to chronic disease (15).

\footnotetext{
* Corresponding author: Khaled Ali Alawaini

Student at a memorial university, Biochemistry department. Canada.
} 
Hepatitis B is a particularly major health problem in on the continent of Africa (16). The prevalence of HBV is roughly $12.1 \%$ in Sudan, which is similar to other African countries such as Burundi (15.6\%), and the Central African Republic (14\%), and higher than Nigeria (5\%) and Ethiopia (7\%) (17). However, in Tunisia, the prevalence of HbsAg ranges from 4 to $7 \%$ (18), while in Libya, the overall incidence of hepatitis B was $2.2 \%(11,19)$ and higher among males than females (1.4:1.0) (19). Surveillance is needed to guide public health policy and control of viral hepatitis spread in Libya efficiently, which requires reliable epidemiological data. Therefore, we determined the prevalence of hepatitis B viruses among the Libyan population and analyzed the risk factors.

\subsection{Objective}

To estimate the prevalence of HBV within the Libyan population.

\section{Methods}

The survey was started in November 2010 and completed in January 2011. The incidence data were based on the analysis of files (official records) from January 1, 2005, to December 31, 2010; the prevalence of HBV was calculated based on the total number of regular other patients who attended the Al Zawia Street Hospital in Tripoli, the capital city of Libya. A hundred (100) patients diagnosed with HBV participated in the survey to determine the risk factors for infection. A structural questionnaire and face-to-face interviews were carried out to collect information regarding the age, education, blood receipt, and surgery history of patients, etc. We entered the data into Microsoft Excel 2016 for analysis.

\section{Results}

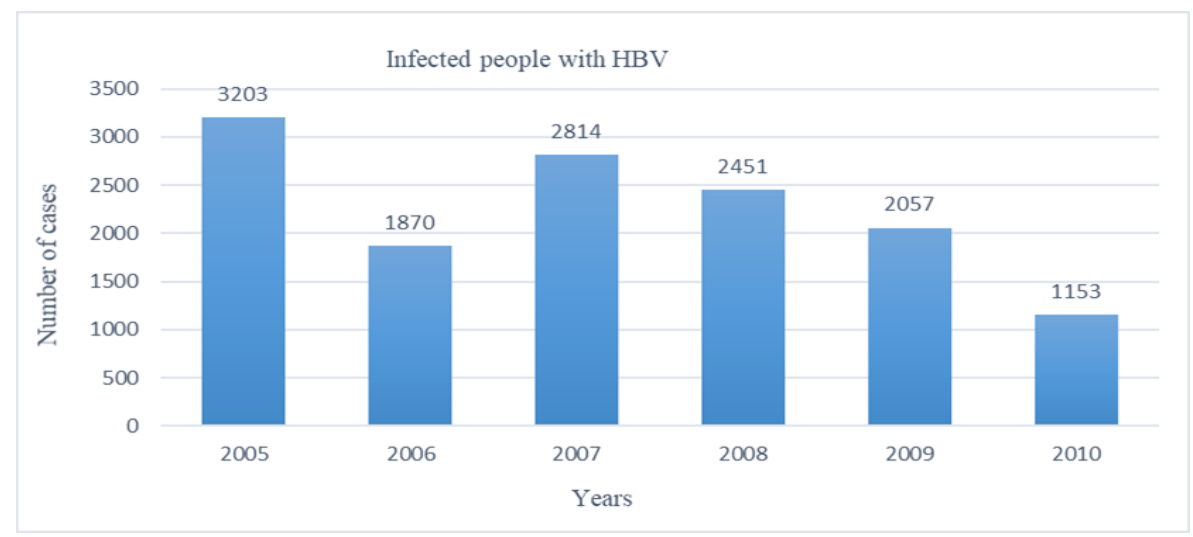

Figure 1 Prevalence of HBV from 2005 to 2010.

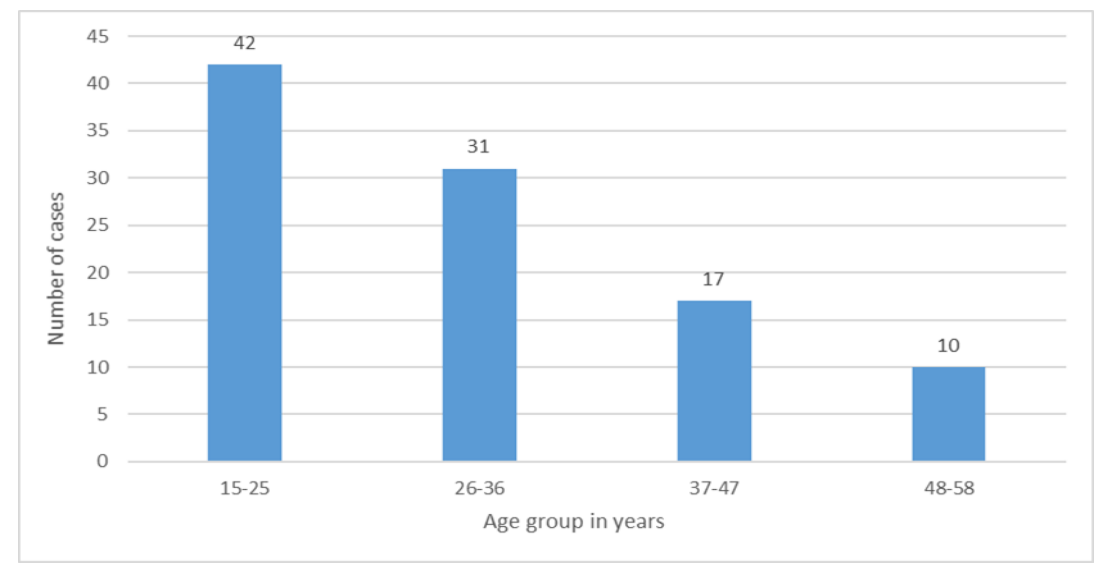

Figure 2 Prevalence of HBV among different age groups 
Table 1 Prevalence of HBV among people according to the gender

\begin{tabular}{|l|l|}
\hline A: Sex & Number of cases \\
\hline Males & 69 \\
\hline Females & 31 \\
\hline Total & 100 \\
\hline B: Status & Number of cases \\
\hline Single & 55 \\
\hline Married & 45 \\
\hline Total & 100 \\
\hline
\end{tabular}

In this study, men were more numerous than women, as shown in Table 1 (69\%vs31\%), with a ratio of 1:2.22.

Table 2 The incidence of HBV by risk factors

\begin{tabular}{|l|l|}
\hline A: Education & Number of cases \\
\hline Uneducated & 8 \\
\hline Low educated & 49 \\
\hline High educated & 43 \\
\hline Total & 100 \\
\hline B: Personal contact & Number of cases \\
\hline Blood transfusion & 0 \\
\hline Surgical operation & 15 \\
\hline Sharing needles & 2 \\
\hline Unknown causes & 13 \\
\hline Total & 30 \\
\hline
\end{tabular}

\section{Discussion}

The incidence of HBV cases averages about $2 \%$ in developed countries; the majority is low. However, the incidence reaches about $8 \%$ in developing countries, due to sex, age, and economic status being essential risk factors (20). Countries were classified according to low $(<2 \%)$, intermediate $(2-8 \%)$, or high $(>8 \%)$ endemic rates of those infected with HBsAg (19). The estimated number of chronic HBsAg carriers in Libya lies between 120.000 and 150.000 (18). Many studies in Libya concluded that the prevalence of HBsAg within the Libyan population was about 2.2\%. (11). As a result, Libya is considered in the middle zone of the HBV epidemic, as classified by the WHO (21). The incidence of HBV is different from one area to another. However, the highest rate was in Sirt, located in the north-central region of the county (6.6\%). In contrast, the lowest incidence was in Benghazi (1.0\%) (19). In our statistical study, which depended on available data, we found that 13548 cases carried HbsAg recorded from 2005 to 2010, and the rates were very high in 2005 compared to 2010 (3203vs1153). However, the number of cases decreased by 23.64\%, 13.8\%, 20.77\%, 18.09\%, and $8.51 \%$ from 2005 to 2010, respectively, as shown in Figure 1. Suggested this could be due to the efforts made to control the infection. Therefore, in our study, interview with a hundred (100) carried HbsAg, (31\%vs 69\%) women and men, respectively, with a ratio of 1:2.2, provided information about the disease. In Libya, Daw and Elbouzedi mentioned (19) out of 107,848 infected people, $39.2 \%$ were females versus $61.8 \%$ males. A nother study in Libya carried out on more than 65000 individuals infected with HBV and HCV showed that the overall seroprevalence of $\mathrm{HbsAg} 2.2 \%$ and was lower in females (42.3\%) than males (58.7\%) (22). A similar study in 
2015 on 125 persons showed that about $2 / 3$ of the infected were males (23). Our study revealed that the rate of HBV infections decreased from $42 \%$ for youth aged 15 to 25 years to $10 \%$ for adults aged 48 to 58 years. This viaration between youth and adulthood ages suggests that transmission differences between age groups could be due to personal behaviours. The risk of transmission through sexual intercourse, means that youth may be more susceptible to other high risk behaviours, such as sharing needles among addicted individuals. Only 30 patients provided full information regarding the transmission of the virus; $6.66 \%$ were addicts, $43.3 \%$ had been infected through exposure to surgical operation, and $50 \%$ had unknown causes. Conversely, out of 100 hepatitis B carriers, 55\% were not married, and $45 \%$ were married, with their partner also being infected $4.4 \%$. There was also an association between literacy and the disease. However, $57 \%$ of patients were low or not educated. Even though, the prevalence of HBsAg (2.2\%) in Libya (24) is still in the low limit, as recognized by the World Health Organization (WHO), but more attention should be taken to minimize the prevalence of the virus.

\section{Conclusion}

In addition to the viral screening of blood donors, hospital admissions, and mandatory vaccinations of neonatal babies against HbsAg to prevent the spread of the virus from an infected mother to her child, more awareness and guidance regarding disease transmission could reduce the spread of the infection to the lowest limit.

\section{Compliance with ethical standards}

\section{Acknowledgments}

Our gratitude to all the staff and patients at Al Zawia street hospital for their helping and corporation in this study.

\section{Disclosure of conflict of interest}

The authors declare no conflict of interest.

\section{Statement of informed consent}

Patients in this study gave their informed consent.

\section{References}

[1] Shi YH, Shi C He. Molecular characteristics and stages of chronic hepatitis B virus infection. World J Gastroenterol. 2009; 15(25): 3099-3105.

[2] Madihi S, Syed H, Fatiha Lazar F, Zaydi A, Benani A. A Systematic Review of the current hepatitis B viral infection and hepatocellular carcinoma situation in Mediterranean countries. Biomed research international volume. 2020; 1-16.

[3] Wilkins T, Zimmerman D, Schade R, Hepatitis B: Diagnosis and treatment. Am fam physician. 2010; 81(8): 965972.

[4] Kitab B, El Feydi E, Afifi R, Trepo C, Benazzouz M, Essamri W, Zoulim F, Chemin, Salih H, Ezzikouri S, Benjelloun $\mathrm{S}$. Variability in the precore and core promoter regions of HBV strains in Morocco: Characterization and impact on liver disease progression plos one. 2012; 7(8): 42891.

[5] Mudawi H. Epidemiology of viral hepatitis in Sudan. Clin Exp Gastroenterol. 2008; 1: 9-13. Fayyaz K, Shafique M, Ali S, Khan S, Khan A, Majeed S, and Butt A. Hepatitis B carrier, diagnosis among volunteer blood donor students at Quaid-I- azam medical college Bahawalpur. The professional.2002; (9).03.

[6] Fayyaz K, Shafique M, Ali S, Khan S, Khan A, Majeed S, and Butt A. Hepatitis B carrier, diagnosis among volunteer blood donor students at Quaid-I- azam medical college Bahawalpur. The professional.2002; (9).03.

[7] Schillie S, Vellozzi C, Reingold A, Harris A, Haber P, Ward J, Nelson N. Prevention of hepatitis B virus infection in the United States: Recommendations of the advisory committee on immunization practices. Recommendations and reports. 2018; 67(1): 1-31 CDC.

[8] Badawi M, Mohammed A, Mohammed MS, Saeed M, Ali EY, Khalil A. A diagnostic laboratory-based study on the frequency and distribution of viral hepatitis B and C Among Sudanese. Open Virol J. 2017; 11: 98-107. 
[9] Elzouki A. Hepatitis B infection in Libya: The magnitude of the problem the Libyan Journal of infectious diseases. 2008; (2): 1.

[10] Block T, Alter H, London W, Bray M. A historical perspective on the discovery and elucidation of the hepatitis B virus. Antiviral res. 2016; 131: 109-23.

[11] Salem M, Elnifro E, Alshuwen F. Molecular analysis of hepatitis virus isolate in Libya: Predominant circulation of hepatitis B virus genotype D. Journal of gastroenterology and hepatology Research. 2012; (7): 119-121.

[12] Wu C, Chen Y, Cao L, Chen X, Ji Lu M. Hepatitis B virus infection: Defective surface antigen expression and pathogenesis.World J Gastroenterol. 2018; 24(31): 3488-3499.

[13] Cheng J, Dai Y, Yan L, Zhou H, Xu X, Sun C, Wang Z. Clinical characteristics and correlation analysis of subjects with chronic hepatitis B virus (HBV) infection and sustained low levels of hepatitis B surface antigen (HBsAg). Med Sci Monit. 2018; 24: 1826-1835.

[14] Shi Y, Shi C. Molecular characteristics and stages of chronic hepatitis B virus infection. World J Gastroenterol. 2009; 15(25): 3099-3105.

[15] Yim H, Lok A. Natural history of chronic hepatitis B virus infection: What we knew in 1981 and what we knew in 2005. Hepatology. 2006; 43(2): 173-181.

[16] Attia M. Prevalence of hepatitis B and C in Egypt. Antivir Ther. 1998; (3): 1-9.

[17] Mursy S, Mohamed S. Knowledge, attitude, and practice towards Hepatitis B infection among nurses and midwives in two maternity hospitals in Khartoum, Sudan BMC public health. 2019; 19: 159.

[18] Hannachi N, Fredj N, Bahri O, Thibault V, Ferjani A, Gharbi J, Triki H, Boukadida J. Molecular analysis of HBV genotypes and subgenotypes in the Central-East region of Tunisia. Virol J. 2010; 7: 302.

[19] Daw MA, El-Bouzed A. Prevalence of hepatitis B and hepatitis C infection in Libya: results from a national population-based survey. BMC infect dis. 2014; 14: 17.

[20] Gad MA, Metwally MA, Eissa HA, Gehad MA, Rayan MM. Antenatal screening for hepatitis B virus infection. Benha med j. 2017; 34 (2): 113-118.

[21] Shambesh MK, Franka EA, Ismail FF, Elosta MA. Occult hepatitis B virus infection among blood donors; North middle Libya. International blood research \& review. 2016; 6(2): 1-7.

[22] Elzouki AN, Smeo IMN, Sammud M, Elahmer O, Daw M, Furarah A, Abudher A, Mohamed MK. Prevalence of hepatitis $B$ and $C$ virus infections and their related risk factors in Libya: a national seroepidemiological survey. EMHJ. 2013; (7): 589-99.

[23] Mohamed A, Elazomi A, Araibi E, Shawesh f, Abdulhameed T, Almrabet W, Alghoull A, Alkhboli A. The prevalence of HBV in the city of Zawia, Libya. International journal of Microbiology and Mycology. 2020; (2): 1-6.

[24] Alemam H, Omar A, Abadi S, Salem M, Elghawi L, Bashein A. A comparative study of alkaline phosphatase level in serum of patients with end-stage renal disease, viral hepatitis (C), and (B). The 4th Annual conference on theories and applications of basic and biosciences. 2020; 291-298. 